\title{
STUDI KOMPARASI DAN DAMPAK HASIL KEPUTUSAN GUGATAN PERDATA PENCEMARAN LINGKUNGAN BUDIDAYA IKAN LAUT DI PULAU BINTAN
}

\author{
Romi Novriadi \\ Pengendali Hama dan Penyakit Ikan Ahli \\ Balai Budidaya Laut Batam \\ Direktorat Jenderal Perikanan Budidaya, Kementerian Kelautan dan Perikanan \\ E-mail: Romi_bbl@yahoo.co.id
}

Diterima 3 Juli 2012- Disetujui 22 Nopember 2013

\begin{abstract}
ABSTRAK
Faktor-faktor yang mempengaruhi dalam mendukung produksi budidaya ikan laut adalah pengendalian hama, penyakit ikan, dan kesehatan lingkungan. Saat ini, penurunan kualitas lingkungan budidaya ikan laut kerap terjadi disebabkan oleh: kegiatan budidaya itu sendiri, berbagai kegiatan industri, pertambangan serta aktivitas rumah tangga. Pada kajian ini, objek penelitian difokuskan kepada hasil keputusan Mahkamah Agung terhadap dua gugatan class action masyarakat akibat penambangan Bauksit yang tidak bertanggung jawab di Pulau Bintan. Makalah ini bertujuan untuk mengidentifikasi faktor-faktor pendukung keberhasilan gugatan perdata class action akibat aktifitas pertambangan. Analisis data dilakukan secara induktif, yang diperoleh dari pengamatan langsung dan pencermatan dokumen dengan membandingkan hasil keputusan dua gugatan class action yang dilakukan oleh masyarakat pembudidaya ikan di Pulau Bintan. Hasil kajian menunjukkan faktor analisa parameter air laut pada laboratorium yang sudah terakreditasi dan kelengkapan administrasi usaha budidaya memiliki pengaruh yang sangat signifikan terhadap keberhasilan gugatan perdata class action. Hasil kajian juga menunjukkan dampak penurunan produksi dan peningkatan angka pengangguran akibat menurunnya aktivitas produksi di dua lokasi yang terkena dampak pencemaran limbah. Namun, kondisi ini memberikan pengalaman positif di kalangan pembudidaya tentang tahapan audit lingkungan yang harus dilakukan berdasarkan standard dan acuan mutu yang memiliki kekuatan hukum di pengadilan.
\end{abstract}

Kata kunci: gugatan class action, pencemaran lingkungan, bauksit, kerugian ekonomi, budidaya perikanan, kerapu macan

\section{Abstract : Comparison Study and Impact of Claim on Court of Justice on Marine Aquaculture Environmental Pollution in Bintan Island. By Romi Novriadi.}

The factors influence on aquaculture production consist of: control of pest, fish diseases, and environmental quality. At present, decreasing on marine environment quality caused by farming activities, industrial activities, mining activities and domestic activities. In this study, the object is more focused on the decision of Supreme Court against two communities class action due to irresponsible Bauxite mining activities in Bintan Island. This study aimed to investigate the success factors supporting on court of justice in mariculture environmental pollution caused by bauxite mining activities. Data were analyzed by inductive approach through direct observation and documents analysis by comparing the results of two class action decisions conducted by fish farmer communities in Bintan Island. The results showed that the factors of seawater parameters in accredited laboratories and complete administrative requirements during the cultivation period has a very significant influenced on the successful of civil class action on court of justice. The results also show the impact of a decrease in production and increase in unemployment due to the decline production activity at the two sites affected by water contamination. However, these conditions provide a positive experience among the fish farmers about the environmental audit activities that should be done based on the reference standards and quality index which has a power of law in front of the court.

Keywords : class action lawsuit, environmental pollution, bauxite, economic losses, aquaculture, tiger grouper

\section{PENDAHULUAN}

Sistem budidaya perikanan yang terdiri atas sistem budidaya di air tawar, air payau maupun di lingkungan air laut telah mengalami perkembangan yang cukup pesat. Menurut data FAO (2011), dalam kurun waktu 1970-2008, terus mengalami peningkatan hingga mencapai pertumbuhan rata-rata $8,3 \%$ per tahun. Sementara kegiatan perikanan tangkap cenderung stabil bahkan mengalami penurunan akibat pola dan frekuensi tangkap yang berlebihan dan tidak bertanggungjawab. Oleh karena itu, untuk tetap dapat memenuhi kebutuhan ikan secara global yang terus meningkat, produksi perikanan budidaya dunia diharapkan dapat mencapai 80 Juta ton di tahun 2050 (FAO, 2011).

Posisi Pulau Bintan yang strategis baik jika ditinjau dari aspek geografis maupun ekonomi serta potensi wilayah untuk kegiatan budidaya ikan yang cukup besar menjadikan wilayah ini sebagai salah satu daerah yang ditetapkan sebagai sentra produksi budidaya ikan laut di Indonesia. Namun, seiring dengan perkembangan industri budidaya, pembangunan sektor lain, seperti: sektor pertambangan yang tidak dilengkapi dengan kinerja pengelolaan lingkungan yang baik dapat menjadi faktor penghambat bagi keberlanjutan produksi perikanan budidaya. Kondisi ini dapat menjadi 
potensi konflik kepentingan terlebih apabila komponen kegiatan produksi sektor pertambangan tidak mampu menanggulangi kerusakan lingkungan yang ditimbulkan (Fandelli et al., 2006).

Potensi konflik juga muncul akibat lemahnya kerangka hukum yang mengatur tata ruang wilayah untuk kegiatan perikanan budidaya serta tidak konsistennya penerapan audit lingkungan sesuai dokumen AMDAL yang dapat dijadikan sebagai early warning system bagi kondisi kualitas lingkungan. Konsekuensinya, pihak pembudidaya yang sangat bergantung terhadap kesehatan dan kualitas lingkungan akan menjadi pihak yang terus dirugikan akibat cemaran limbah cair yang telah melebihi baku mutu untuk kegiatan produksi ikan budidaya. Bahkan tidak jarang cemaran limbah cair ini menyebabkan tingkat kerugian ekonomi dan kematian ikan yang cukup besar bagi para pembudidaya. Langkahlangkah gugatan perdata perlu dilakukan untuk mencari penyelesaian masalah bagi beberapa komponen kegiatan pertambangan yang belum berhasil menanggulangi kerusakan lingkungan.

Tujuan dari kajian ini adalah untuk melakukan analisis terhadap komponen instrumen audit yang dapat mendukung keberhasilan gugatan class action dan dampak kerusakan lingkungan akibat kegiatan pertambangan serta melakukan evaluasi terhadap metoda audit lingkungan yang dilakukan oleh para pembudidaya ikan. Fokus kajian dilakukan pada Keputusan Mahkamah Agung No. 705 K/Pdt/2011 dan No. 808 K/Pdt/2009. Dimana dua direktori putusan ini memberikan hasil gugatan class action yang berbeda untuk kasus kematian ikan yang sama, kerapu macan (Epinephelus fuscogutatus) oleh pencemaran limbah pertambangan yang sama, pertambangan bauksit. Hasil kajian ini diharapkan dapat menjadi acuan dalam menyusun komponen audit lingkungan yang dapat mendukung keberhasilan pembudidaya ikan dalam mengajukan gugatan class action akibat cemaran limbah cair pertambangan.

\section{METODOLOGI}

Penelitian ini dilakukan selama dua tahun, 2009 sampai dengan 2011, di Pulau Bintan, Provinsi Kepulauan Riau dengan pertimbangan bahwa daerah ini memiliki potensi pencemaran lingkungan kegiatan budidaya ikan laut akibat limbah cair hasil kegiatan pertambangan bauksit.

Penelitian ini merupakan penelitian kualitatif dengan menggunakan metode pengamatan dan studi dokumen. Penentuan metode ini merujuk pada penjelasan Arikunto (2010) dengan tujuan untuk mendapatkan data perbandingan yang memiliki kepercayaan tinggi. Teknik pengumpulan data dilakukan melalui wawancara, observasi dan diskusi sejarah usaha budidaya ikan di pulau Bintan. Sebagai data primer, selain teknik live in untuk mendapatkan data faktual, peneliti juga memanfaatkan data sekunder berupa dokumen ijin usaha budidaya ikan, dokumen produksi budidaya, dokumen analisa lingkungan pembudidaya dan dua direktori putusan Mahkamah Agung terhadap gugatan class action yang dilakukan oleh masyarakat pembudidaya ikan di Batu Licin dan Senggarang Pulau Bintan akibat pencemaran limbah cair bauksit. Dokumendokumen ini penting sebagai indikator subjektif kerugian usaha budidaya akibat cemaran limbah cair.

Analisis data dilakukan berdasarkan tahapan pelaksanaan audit lingkungan yang dikemukakan oleh Fandelli et al., (2006) yang meliputi tiga tahap, yaitu pre audit, site audit, dan post audit. Pre audit merupakan tahapan pengumpulan data yang diperoleh melalui informasi dan bahan yang disampaikan oleh para pembudidaya ikan. Hasil pre audit kemudian diverifikasi dengan melakukan kunjungan lapangan (site audit). Pada tahapan site audit ini sangat bergantung kepada hasil wawancara dengan pembudidaya ikan yang mencakup metodologi, topik prioritas, jadwal waktu, tempat analisa dan bentuk laporan. Pada tahapan ini metodologi penelitian yang baik sangat menentukan tingkat objektivitas bukti/temuan audit yang akan tercantum dalam laporan. Seluruh hasil audit lingkungan yang berupa bukti-bukti objektif disampaikan kepada pembudidaya ikan sebagai komponen utama dalam post audit.

\section{KEGIATAN PEMBANGUNAN DI PESISIR BINTAN}

Kegiatan pembangunan di pesisir Bintan yang memanfaatkan sumberdaya alam, selain mempengaruhi komponen fisik tanah dan udara, juga mempengaruhi komponen air. Perubahan kualitas air sangat berpengaruh terhadap keberlanjutan produksi perikanan budidaya. Oleh sebab itu, untuk menjaga kualitas lingkungan perairan, sangat penting dilakukan proses audit lingkungan dan manajemen pengelolaan lingkungan yang baik bagi setiap industri yang memiliki cemaran limbah cair yang dapat berkontribusi pada perubahan fisik komponen air (Pluta dan Trembaczowski, 2001).

Sebuah kegiatan usaha yang mengeluarkan cemaran limbah cair harus selalu diamati. Hal ini sesuai dengan prinsip "Polusi tidak mengenal batas wilayah dan negara", sehingga harus tetap waspada jika ada indikasi pencemaran di sekitar perairan. Terkait dengan hal tersebut, sektor pertambangan merupakan sektor yang wajib melaksanakan audit lingkungan sesuai dengan Keputusan Menteri Lingkungan Hidup No. 30 tahun 2001. Oleh karena itu, situasi yang terjadi di Pulau Bintan dapat berpotensi konflik apabila audit lingkungan tidak dilakukan secara rutin dan cemaran limbah cair berdampak negatif terhadap kesehatan lingkungan produksi budidaya perikanan di lokasi yang memiliki ruang aktivitas ekonomi yang sama (Kurniasari et al., 2012). 


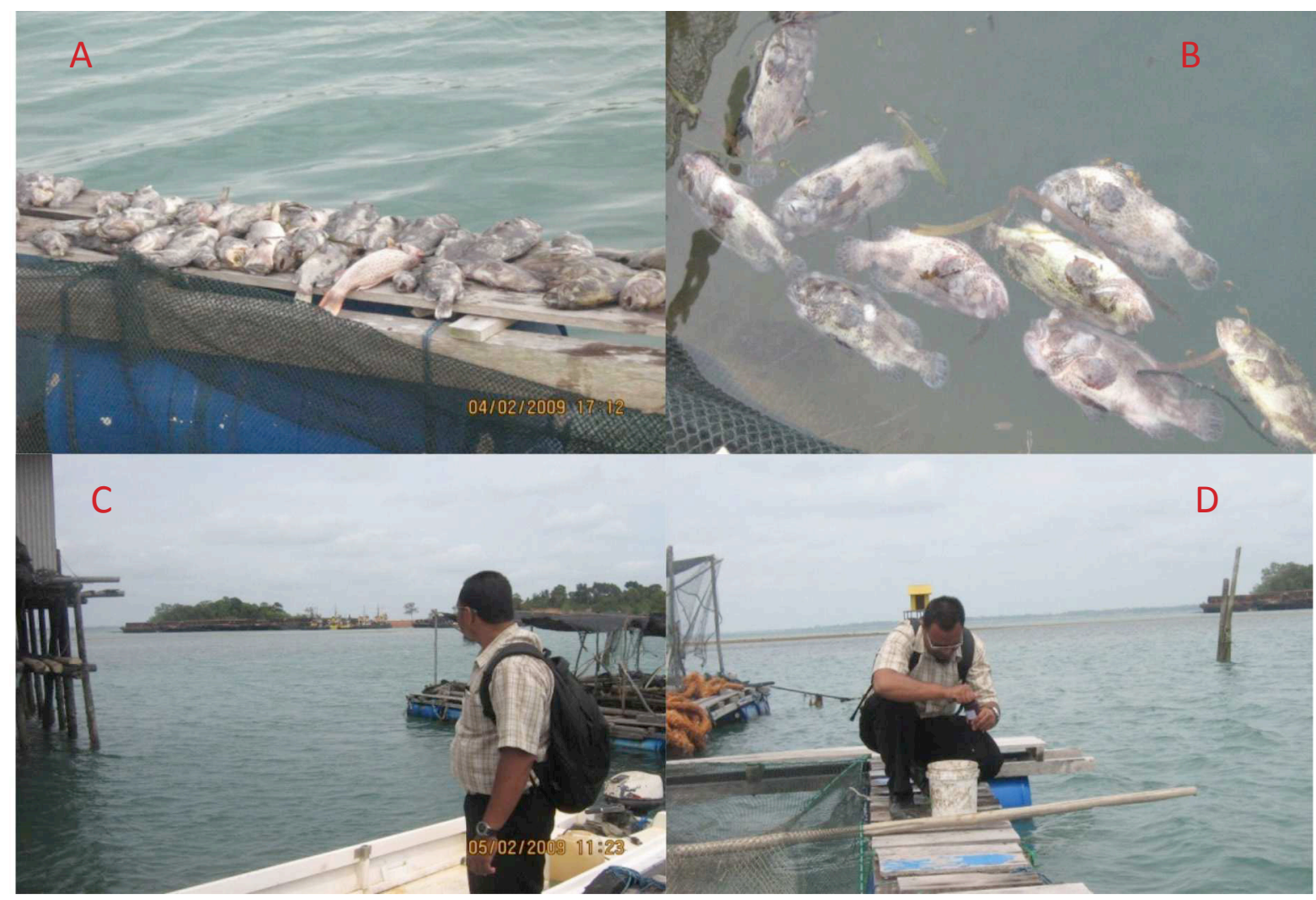

Gambar 1. Dampak dan Kegiatan Eksploitasi Bauksit di Pulau Bintan. Searah Jarum Jam (A): Kematian Ikan Kerapu Macan (Epinephelus Fuscoguttatus) Yang Sudah Diangkat Dari Keramba; (B): Ikan Kerapu Macan yang Mati di Dalam Media Lingkungan Pemeliharaan; (C): Gambaran Lokasi Eksploitasi Bauksit yang Dekat Dengan Lokasi Budidaya Perikanan; dan (D) Salah Satu Komponen Audit Internal, yakni Pengambilan Sampel Secara Random di Lokasi Budidaya.

Berdasarkan pengamatan pada site audit diketahui bahwa terdapat konflik pengelolaan wilayah pesisir antara pemerintah, komunitas penambang bauksit dan komunitas pembudidaya ikan kerapu. Sementara kewenangan dalam mengatur dan mengelola sumberdaya laut dan pesisir hanya dimiliki oleh Pemerintah. Konflik umumnya terjadi apabila kegiatan pengelolaan tidak diikuti oleh penegakan konsekuensi atas pelanggaran pengelolaan yang dilakukan sehingga mengakibatkan kerugian di pihak pemanfaat yang lain (Kurniasari et al., 2012). Berdasarkan hasil wawancara dengan masyarakat diketahui bahwa kegiatan budidaya perikanan telah dilakukan selama dua sampai tiga generasi sementara aktivitas pertambangan beroperasi dalam waktu yang terbatas. Sehingga dapat dikatakan bahwa kasus pencemaran lingkungan yang mengakibatkan kerugian ekonomi hingga miliaran rupiah merupakan wujud kongkrit dari pemaknaan tata ruang dan wilayah yang masih bersifat abstrak.

\section{Hasil audit lingkungan}

Dalam kegiatan audit lingkungan, komponen atau parameter yang dianalisa dilakukan secara keseluruhan dengan mempertimbangkan parameter yang sesuai dengan cemaran limbah cair hasil kegiatan penambangan bauksit.

Tabel 1. Hasil Audit Lingkungan di Dua Lokasi Budidaya yang Terkena Dampak Kegiatan Pertambangan Bauksit.

\begin{tabular}{lcccc}
\multirow{2}{*}{ Lokasi } & \multirow{2}{*}{ Satuan } & \multicolumn{3}{c}{ Hasil Analisa } \\
\cline { 3 - 5 } & \multirow{2}{*}{ Batu Licin ${ }^{1)}$} & Nikel (Ni) & Plumbum (Pb) & Alumina (Al) \\
Senggarang ${ }^{1)}$ & $\mathrm{mg} / \mathrm{l}$ & $0,79-0,86$ & $0,79-0,86$ & $4,36-8,17$ \\
\hline
\end{tabular}

Keterangan: ${ }^{1)}$ Jumlah sampel masing-masing lokasi : 3 sampel

Sumber: Dokumen Keputusan Mahkamah Agung No. 705 K/Pdt/2011 dan No. 808 K/Pdt/2009 
Berdasarkan hasil audit lingkungan dan direktori Keputusan Mahkamah Agung No. 705 K/Pdt/2011 dan No. 808 K/Pdt/2009, parameter yang menjadi conflict of interest, diketahui telah berada di atas baku mutu lingkungan yang ditetapkan oleh Kementerian Lingkungan Hidup. Di lokasi Batu Licin, konsentrasi Alumina (Al) dengan kisaran 4,36 - 8,17 sudah berada diatas lethal concentration, terlebih bila berada di dalam air laut yang bertransformasi dalam bentuk ion dari bentuk padatan dan akan menyerang syaraf ikan. Tingkat infeksi saraf ini akan semakin diperparah oleh kondisi derajat keasaman $(\mathrm{pH})$ yang rendah akibat limbah cair pencucian bauksit yang mengandung larutan asam. Hal yang sama juga ditunjukkan oleh parameter logam Nikel ( $\mathrm{Ni}$ ) dan Plumbum (Pb) yang keduanya, 0,79 -0,86 mg/l, telah melewati baku mutu lingkungan yang mempersyaratkan konsentrasi < 0,1 mg/l untuk menjamin keberlanjutan produksi ikan budidaya. Peningkatan konsentrasi kedua logam berat terlarut dalam air tersebut dapat mengakibatkan kerusakan pada insang dan sistem saraf ikan (Jarup, 2003).

Situasi yang sama juga ditunjukkan oleh kondisi kualitas lingkungan di lokasi dua, yakni di lokasi perairan senggarang. Konsentrasi Alumina (Al) berada pada kisaran 6,11 - 8,12 mg/l, sementara Plumbum (Pb) memiliki konsentrasi 0,2596 mg/l dan Nikel (Ni) memiliki konsentrasi 0,318 mg/l. Kondisi ini kembali menegaskan bahwa kesehatan lingkungan di kedua lokasi budidaya tidak layak untuk kegiatan produksi. Namun, kedua hasil analisa tersebut memiliki pandangan yang berbeda pada hasil direktori putusan Mahkamah Agung.

Berdasarkan direktori Keputusan Mahkamah Agung No. 705 K/Pdt/2011 dan No. 808 K/Pdt/2009, diketahui bahwa hasil analisa di lokasi perairan Senggarang lebih kuat dimata hukum dibandingkan hasil analisa di lokasi batu licin. Hal ini utamanya disebabkan oleh penilaian kualitas lingkungan yang dilakukan untuk sampel air di Senggarang di lakukan di laboratorium penguji yang telah terakreditasi KAN 17025:2005. Sementara analisa sampel yang dilakukan untuk wilayah Batu Licin dianggap dilakukan di laboratorium yang belum terakreditasi, walaupun seluruh tahapan audit lingkungan seperti pengambilan sampel dan proses preparasi sampel telah memenuhi Standar Nasional Indonesia.

Sistem akreditasi merupakan perangkat instrumen yang ditetapkan berdasarkan sistem birokrasi dalam negeri yang menerapkan prinsip-prinsip sistem manajemen mutu dan dapat dianggap sesuai dengan syarat hukum dan berbagai peraturan Internasional lainnya (Menteri Perdagangan RI, 1994; Suardi, 2003). Namun, saat ini di Indonesia, masih terdapat laboratorium penguji yang belum mendapatkan sertifikat akreditasi. Sehingga para pembudidaya ikan perlu mendapatkan sosialisasi yang efektif terhadap kekuatan hukum sebuah hasil analisa yang dihasilkan oleh laboratorium terakreditasi.
Menurut Sukirno (1985), pembangunan ekonomi adalah suatu proses yang menyebabkan pendapatan per kapita kelompok masyarakat meningkat dalam jangka waktu yang panjang. Pembangunan yang dilakukan terkadang tidak mencerminkan rasa keadilan khususnya bagi para pembudidaya ikan yang jarang mendapatkan pendidikan tinggi. Permasalahan ekologi ini menjadi permasalahan yang cukup rumit untuk diselesaikan oleh para pelaku budidaya ikan di kawasan pesisir yang berdekatan dengan lokasi pertambangan. Penyelesaian yang dilakukan untuk mengatasi dosa-dosa ekologi ini tak jarang membutuhkan koordinasi lintas kementerian/ lembaga dan lintas sektoral dan bahkan membutuhkan waktu yang cukup lama.

Dalam pengajuan gugatan perdata, para pembudidaya diharapkan memiliki catatan administrasi yang lengkap, dimulai dari kepemilikan Surat ljin Usaha Perikanan, catatan pembelian benih, pakan, sarana dan prasarana kegiatan budidaya hingga kepada catatan penggajian karyawan secara lengkap. Hal ini dimaksudkan untuk dapat memperkirakan jumlah kerugian yang diakibatkan oleh pencemaran limbah pertambangan. Berdasarkan direktori Keputusan Mahkamah Agung No. 705 K/Pdt/2011 dan No. 808 K/Pdt/2009, kedua lokasi budidaya yang terkena dampak cemaran limbah cair telah memiliki catatan kegiatan produksi yang cukup baik. Hal ini mendapatkan apresiasi yang sangat baik dari pihak pengadilan dan mempermudah pihak pengadilan dalam memperhitungkan tingkat kerugian yang dialami oleh para pembudidaya.

\section{Aspek Sosial Ekonomi}

Berdasarkan kajian pre site di lokasi budidaya ikan, dampak kegiatan penambangan bauksit pada bidang ekonomi masyarakat Batu licin dan Senggarang sangat besar. Pada umumnya masyarakat kehilangan sumber pendapatan karena lingkungan budidaya sudah tidak layak untuk mendukung keberlanjutan produksi. Jumlah kerugian materi masyarakat masyarakat Batu Licin dan Senggarang hampir mencapai 4 Milyar Rupiah.

Masyarakat Batu licin memperkirakan kerugian sebesar:

1. Kerugian karena kematian ikan Kerapu macan (Epinephelus fuscoguttatus) sebanyak 27.673 ekor $=22.138,4 \mathrm{Kg} \times \mathrm{Rp} .80 .000$,- per ekor = Rp.1.771.072.000,-

2. Kerugian atas pembelian makanan ikan, perawatan dan pemeliharaan ikan yang telah dikeluarkan pembudidaya sebesar Rp.281.621.000,-

Sementara kerugian yang dialami oleh masyarakat Senggarang adalah sebesar:

1. Kerugian karena kematian ikan Kerapu Macan (Epinephelus fuscoguttatus) $6.300 \mathrm{~kg} \times \mathrm{Rp} .7500=$ Rp. 945.000 .000 
2. Kerugian atas pembelian makanan ikan, perawatan dan pemeliharaan ikan yang telah dikeluarkan pembudidaya sebesar Rp. 420.000.000,-

Di wilayah Batu Licin dan Senggarang, jumlah pembudidaya ikan dan nelayan hampir mencapai $70 \%$. Sebelum adanya pertambangan, kegiatan budidaya dan menangkap ikan adalah sumber mata pencaharian utama mereka. Saat ini, akibat buangan limbah cair, pola distribusi ikan berubah dan ikan yang berada dalam pemeliharaan memiliki kandungan logam berlebihan di insang, sehingga mata pencaharian masyarakat berkurang.

Potensi konflik masyarakat pembudidaya dan masyarakat pertambangan akan terus berulang apabila aturan formal tentang konsep tata ruang wilayah tidak diterapkan secara maksimal (Kurniasari et al., 2012). Potensi konflik tersebut bahkan tidak jarang mendorong para pembudidaya melakukan gugatan class action apabila tingkat kerugian dan kematian ikan telah melebihi $70-80 \%$ dari total produksi yang mereka lakukan. Oleh karena itu, pengelolaan sumberdaya alam secara bijaksana dengan tetap memelihara dan meningkatkan kualitas keanekaragaman hayati harus terus diupayakan.

Berdasarkan kajian post site setelah hasil putusan gugatan perdata class action dibacakan, para pembudidaya ikan baik yang berhasil ataupun tidak berhasil, tetap dituntut untuk mencari lokasi baru dengan kualitas lingkungan yang lebih baik. Bahkan tidak jarang beberapa pembudidaya meninggalkan usaha produksi ikan dikarenakan modal dan penentuan lokasi yang cukup sulit dan mahal. Kerusakan lingkungan juga berakibat kepada penurunan jumlah produksi ikan kerapu macan dan peningkatan angka pengangguran akibat menurunnya aktivitas kegiatan produksi budidaya, khususnya di wilayah Batu Licin dan Senggarang.

Solusi lingkungan yang dapat dilakukan adalah dengan selalu melakukan evaluasi Analisis Mengenai Dampak Lingkungan (AMDAL) secara rutin untuk mengetahui pelanggaran lingkungan yang dilakukan oleh para pelaku usaha. Strategi pengelolaan zona khusus untuk kegiatan perikanan budidaya juga mendesak untuk ditetapkan, khususnya di Pulau Bintan. Dengan datadata yang dihasilkan oleh kegiatan monitoring AMDAL tersebut, kebijakan yang tepat, efisien dan efektif dapat dilakukan untuk mencegah kerusakan lingkungan lebih lanjut. Sangat diharapkan partisipasi dari berbagai pihak agar pengelolaan lingkungan yang membutuhkan anggaran cukup besar dapat dilakukan dengan baik.

\section{KESIMPULAN}

Hasil kajian ini menegaskan bahwa dalam melakukan audit lingkungan, masyarakat pembudidaya harus selalu berpatokan kepada aturan dan standar yang memiliki ketetapan hukum di muka pengadilan. Oleh karena itu, harus terus diupayakan peningkatan pemahaman dan kualitas hasil analisa audit lingkungan melalui kerjasama yang kuat antara masyarakat pembudidaya, pemerintah dan organisasi pemerhati lingkungan. Selain itu, dalam skala makro, pengelolaan sumber daya alam hendaknya dilakukan berdasarkan prinsip konservasi dan memperhatikan kondisi lingkungan serta mengacu kepada aturan tata ruang wilayah yang telah ditetapkan, sehingga keberlanjutan produksi dan angka tenaga kerja di sektor budidaya perikanan dapat terus ditingkatkan.

\section{DAFTAR PUSTAKA}

Anonymous. Putusan No. 705 K/Pdt/2011, Direktori Putusan Mahkamah Agung Republik Indonesia. Jakarta

Putusan No. 1808 K/Pdt/2009, Direktori Putusan Mahkamah Agung Republik Indonesia. Jakarta

Fandelli, S., Utami, R.N. dan Nurmansyah, S. 2006. Audit Lingkungan. Gadjah Mada University Press. Yogyakarta.

FAO. 2011. The state of world fisheries and aquaculture 2010. FAO Fisheries and Aquaculture Department. Food and Agriculture Organization of the United Nations. Rome.

Jarup, L. 2003. Hazards of heavy metal contamination. British Medical Bulletin 68: 167-182.

Kurniasari, N., Satria, A. dan Rusli, S. 2012. Konflik dan Potensi Konflik Dalam Pengelolaan Sumberdaya Kerang Hijau Di kalibaru Jakarta Utara. J. Sosek KP Vol. 7 (2).

Menteri Perdagangan. 1994. Kumpulan Tulisan Tentang International Standards Organization. Penerbit PSLH UGM, Yogyakarta.

Pluta, I dan Trembaczowski, A. 2001. Changes of the chemical composition of discharged coal mine water in the Rontok Pond, Upper Silesia, Poland. Environmental ecology 40: 454-457.

Sukirno, S. 1985. Ekonomi Pembangunan Proses, Masalah dan Dasar Kebijakan. Lembaga Penerbit Fakultas Ekonomi Universitas Indonesia. Jakarta. 